\title{
Polic(sh)ing up the Leipzig Main Station: an ethnographic reflection on abjection, space and resistance
}

\author{
Elisabeth Kirndörfer ${ }^{1}$
}

Accepted: 5 August 2021 / Published online: 19 August 2021

(c) The Author(s) 2021

\begin{abstract}
In this article, I explore the interplay of abjection, space and resistance at the example of a protest intervention that reclaims a highly policed urban space in the city of Leipzig (Saxony, Eastern Germany) — the Main Station. Methodologically, I combine ethnographic material collected throughout the process of a performative counter-action attempting to reclaim and re-imagine Leipzig Main Station as a venue and politicized space with a contextual analysis regarding the discursive landscape evolving around and shaping this urban locale. My empirical analysis is structured along the theoretical discussion of abjection: While Butler's theorization (Butler in Bodies that matter, Routledge, New York, 1993) allows me to focus on the formative power of spatial exclusion and the disruptive potential of protest, theoretical accounts in which abjection is conceived as a "threshold zone" or "overlap space" (Sharkey and Shields in Child Geogr 6:239-256, 2008; Vighi et al. in Between urban topographies and political spaces. Threshold experiences, Lexington Books, Lanham, 2014) help me to outline 'abject space' as a space of negotiation and contradiction.
\end{abstract}

Keywords Abjection $\cdot$ Space $\cdot$ Resistance $\cdot$ Citizenship

\section{Introduction: discursive landscapes "after Cologne"}

Since the happenings around the New Year's Eve 2015/2016 in Cologne, when dozens of young women have been sexually harassed by men who were later identified-in the press coverage that followed and the offences that have been reportedas having a "Mediterranean", "North African" or "Arabic appearance" (Arendt et al. 2017, p. 136-138), ${ }^{1}$ the public discourse around asylum and immigration in the

\footnotetext{
11200 out of 1600 offences have been reported in the context of this evening - a good half of it concerned sexual assaults, among them individual cases of rape, and around 1000 oft property crimes. 200 suspects have been identified subsequently $-85 \%$ of them had been immigrated to Germany as refugees,
}

Elisabeth Kirndörfer

elisabeth.kirndoerfer@uni-bonn.de

1 Geographisches Institut Universität Bonn, Meckenheimer Allee 166, 53115 Bonn, Germany 
German context has significantly changed (Vollmer and Karakayali 2017; Hark and Villa 2017). Acclaims of diversity and 'German welcoming culture' have been surpassed by bouts of moral panics rotating around the figure of the 'sexually molesting, unattached, young Muslim man'. One of the discursive effects of this event was an even more pronounced differentiation between "deserving" and "undeserving" migrants (Vollmer and Karakayali 2017, p. 3). This "demonization"2 of postcolonial male refugees (Mecheril and do Mar Castro Varela 2016, p. 10) coincided with the construction of a "North African cultural space" (Espahangizi et al. 2016, p. 17) clearly demarcated from a Western liberal value system. It is at this particular conjuncture of racism, sexism and feminism (Hark and Villa 2017; Dietze 2016a, b; Farris 2016) that German asylum politics became revaluated and anti-immigration discourses gained momentum. This re-(b)ordering dynamic equally affected subsequent crime news reporting, in which, since 2016, "foreigner-specific attributes" have been increasingly mentioned (Arendt et al. 2017, p. 144) - the attribution "North African" even about ninefold (ibid.)

These discursive dynamics which operate until today, I argue, unfold along the production of spaces. They have fostered and reshaped spatial formations of in- and exclusion. The "Hauptbahnhof", the area around the Main Station in Cologne, turned into a symbol for the loss of state control over the effects of the so-called 'refugee crisis' and for the ultimate threat posed by liberal politics to 'vulnerable' citizen subjects-women-in public spaces. Leipzig Main Station, in this paper, is analysed as an urban site that illustrates how these discursive dynamics reverberate in an Eastern German context ${ }^{3}$ : Since 2016, criminalizing discourses sprouting around this urban area increasingly target undocumented migrants from North Africa. This phenomenon becomes the initial point for a small-scale resistance movement initiated by a theatre performer and political activist with a Tunisian background, supported by a group of urban residents who live in different precarious conditions regarding their administrative status, their housing and economic situation. The focus of this paper lies on the moment when, in November 2017, Leipzig Main Station is reclaimed by a group of people from North and Southwest Africa and their German-born allies and transformed into a site of protest.

Footnote 1 (continued)

asylum seekers or migrants. $30 \%$ of the suspects originated from Morocco or Algeria (see Arendt et al. 2017, p. 139).

2 Quotes in German have been translated by the author.

3 Leipzig, located around $150 \mathrm{~km}$ south of Berlin, constitutes, with 575,000 inhabitants, the biggest city in Eastern Germany. Within the East-German context, the city "represents the extremes of urban development" (Großmann et al. 2014, p. 1): After decades of shrinking (extreme population loss and outmigration) and deindustrialization processes after 1990, Leipzig has been considered the most rapidly growing city in Germany since 2011, with a yearly population growth of 10,000 inhabitants. The city is a particularly interesting example for the study of abjection-related processes, as international, "visible" migration which coins the city's political life as well as the urban everyday is still quite a recent phenomenon (Philipps and Rink 2009, p. 400; Münch 2013, p. 263). At the same time, in terms of migration, Leipzig represents an outstanding case within the German East: The proportion of residents with migration histories are, in comparison to other larger cities except Berlin, like Dresden and Erfurt, relatively high (from $6 \%$ in 2000 to $8 \%$ in 2010 , then $11 \%$ in 2014 and a new culmination point of $14 \%$ in 2017 , data provided directly by the Office for Statistics and Elections of the city of Leipzig). 
In order to decipher racializing, sexualizing and classifying discourses with an analytical focus on space-based politics of (b)ordering and resistance, the notion of "abjection" (Kristeva 1982; Tyler 2013; Butler 1993) proves particularly helpful. What I aim at, in sum, is the analysis of Leipzig Main Station through a spacesensitive, ethnographic perspective which fertilizes the concept of 'abjection' for investigating, in a joint manner, racializing discourses and politics of 'displacement' and tactical moves of adaptation, appropriation and resistance. The questions I ask: How can discursive and spatializing processes of 'social abjection' give rise to initiatives of re-claiming and re-appropriating space? How can 'bodies made abject' "take up space"? And which inner fractions and contestations characterize resistant action itself?

I will start with a detailed description of the protest action that forms the centre of my paper in the section "Empirical context". In the section "Empirical material, methods and reflections on my positionality", I will present my methodological framework in which I combine a critical discourse analysis with ethnographic material, and reflect on my positionality within the project. In "Abjection as a "theory of bordering"", I will discuss the concept of 'abjection' from different theoretical standpoints. Here, I mainly focus on the understanding of 'abjection' as an 'overlap zone" (see England 2008; Sharkey and Shields 2008; Vighi et al. 2014) on the one hand, and as a clearly demarcated domain which appears as constitutive for the formation of the subject (cf. Butler 1993; Isin and Rygiel 2007) on the other. This tension will serve as guideline for the structuration of my "Empirical analysis": As a first step, I will demonstrate in what way Leipzig Main Station can be regarded as exemplary for the simultaneous production of urban 'abjects' and a normative urban "centre" constructed along attributes like cleanliness, order and whiteness. The protest action formulated against these politics will then be investigated along Butler's reflection on "disruption" and as a "point of convergence" rife with inner fractions and nuances. I will conclude my findings in the "Concluding remarks" section, opening a discussion on (the limits of) subversion and the particularity of the Eastern German context.

\section{Empirical context}

"It is six o' clock in the evening and freezing cold. We-a group of seven people of diverse backgrounds, appearances, in diverse living situations-stroll across the square which interlinks the Main Station of the City of Leipzig with the historical City centre and think about where we could at best realize Walids theatre performance, in combination with a small protest action. We enter the little park edging that area. We stand in a circle, discussing when to meet again and configure a WhatsApp-group when three police officers pass by, a patrol car following up. The officers stop, bend over in our circle and ask, in direction to me and Charlotte, if "everything's fine". And then, designating Walid: "Do you know him? "I am perplexed and answer him that we are together here. As the officer explains later, it was not only the composition of the group which had intrigued him and his colleague, it was the place in itself 
which legitimized their control: the area around the Hauptbahnhof is labelled as "dangerous zone". What did the officer "see", how did he interpret our gathering? Dealers and buyers? Or, as he suggests later, robbers drawing near a group of students? (Fieldnotes, 6.11.2017).

This vignette captures the moment when the main actors of the protest action, that is at the centre of this paper, meet for the first time: three asylum seekers from Cameroun who stay in an initial reception centre in Leipzig's North-Grace, Draven and Fabrice ${ }^{4}$ - , two students with migration histories living in a leftist housing project—Sina Jinen and Katalyn—, Walid who has migrated from Tunisia to Germany sixteen years before, initiator of our project, and lastly Charlotte and me, both of us born in Germany, employed in research projects dealing with '(post)migration' at a Geographical Institute. We meet at Leipzig Main Station, or rather in the little park that lines the big square in front of it. Walid has chosen this location as it is-in the local media coverage - at the core of criminalizing and racializing discourses. In Walid's view, the "Hauptbahnhof" is symbolic for the violence of the European border regime. Especially people from North Africa are discriminated, criminalized, threatened by deportation and deprived of the possibility to live in legal conditions. His plan, partly in reaction to this, is to organize a protest action which draws attention to the violence that the European external border raised between the African and the European continent exerts on North African societies and bodies as well as on arrival spaces in Europe. His theatre performance "Borders" will be one of its central elements.

The protest action mentioned in the vignette takes place two weeks after this initial encounter. In between, the group has met six times to plan and prepare the event: We have written flyers, drawn banners, collected material. As the analysis below will show, this process was partly marked by tensions and negotiations. The day of the protest is a rainy and windy late afternoon in November and people who cross the square to reach the Main Station, or enter the City Centre, hurry past. We have attached banners with claims for the 'freedom of movement' and 'the border is the problem' written on it, built up a little pavilion, installed a music system which spreads energetic sounds from North and West Africa and a microphone. As cables and other material are delivered with a huge delay, the atmosphere is rather tensed. When it turns dark, Walid initiates the protest with a little speech, followed by the performance of parts of his theatre play "Borders": He tells the story of Abi, who, after a long period full of hope and anxiety reaches his destination: Europe. His journey ends in a complete lack of perspectives: Stuck in an initial reception centre, the protagonist of this play shares his experiences of endless waiting, of criminalization and racism, and his constant fear of being deported. Walid is invisible throughout this performed monologue: With the help of a spotlight, his body appears as a pacing, feverish shadow, now and then lapsing into stillness, on a yellow sheet that we had suspended in between trees. His performance transmits the suffering, fury

\footnotetext{
4 Names have been anonymized.

5 The name of the piece has been anonymized.
} 
and nervousness, which shape the everyday of young people in North Africa, as well as of people who are urged into abject spaces within Europe. Between these theatre miniatures, Walid switches the register and hollers his political message, condemning loudly and angrily the racializing logics of the European asylum regime which excludes migrants who seek for better lives and urges them into a living situation which lack of any perspectives. "Since Europe has built its wall, the living situation is becoming worse in Tunisia, in Algeria and Morocco. We're doing badly there. Today we are here in order to draw attention to this situation!" After Walid's performance and speech, the "stage" is opened and various people with migration histories raise their voices and propagate personal, political messages across the square. Fabien, for instance, a young asylum seeker from South-West Africa, conjures peace and love across racial boundaries in a near to pastoral manner. Charlotte engages in translating his speech. Fabrice and Grace, throughout the whole protest action, spread across the rain-soaked and windy square and dispatch our flyers. They engage in small conversations with the pedestrians. Draven and others, after night fall, perform rap music at the open mic. The music performances attract more and more people-mostly undocumented migrants - who live in more than precarious conditions legally and economically and who, at that moment of the day, 'hang out' at the "Hauptbahnhof". In the end, the small crowd starts to dance-until the police comes and interrupts the party. Partly due to the unpleasant weather conditions not many pedestrians who cross the square attend the intervention, and yet, especially when Walid performs his theatre piece, a small crowd of people gathers in front of our pavilion and listens attentively. Several months later, in Mid-May 2018, this performative action is followed by a protest march, the "Parade for the Freedom of Movement" which unites around two hundred protesters. They march from the Main Station to the park located close to the "Eisenbahnstraße" - the city's only district where the proportion of people with migration histories approximates 20\% (Office for Statistics and Elections 2018) and which constitutes, next to the Main Station, the second "hotspot" for increased police presence. What made this parade special was the fact that most of the protesters were people of colour. This was a "premiere" for Leipzig - a city which is famous for its leftist scene but where migration-based protest remains marginal.

This first outline of the protest, captured in the vignette, points at how abjectifying politics affect everyday life interactions at the Main Station: Our gatherings and activities happen under the eye of the police. The described situation in the vignette evokes Sara Ahmed's discussion of Althusser's interpellation in "Queer Phenomenology" (2006): A police officer calling "Hey you, there!", in this example, recruits the black body as a "strange body", a "body out of place". However, in this situation, the line is not only drawn along the category of being-white or being-black. The interpellation at work here combines notions of gender and race, in referring to the public discourse around the 'male North African (undocumented) immigrant implied in murky affairs', which since the 'Cologne event'-as mentioned in the introduction-is at the heart of migration-related debates. At the day of our performance, the police is again present. However, the situation, at this particular day, is even more ambivalent: As the protest is officially authorized, several police officers "sneak" around the location of our performance without intervening-except for the 
moment, when, in the end, music is deemed too loud. This tension that emerges in spaces where critique and control, centre and margins converge, is at the core of the notion of 'abjection' that I will introduce and discuss after, in the next paragraph, outlining my methodological approach.

\section{Empirical material, methods and reflections on my positionality}

The observations made around the protest action form part of empirical material which has been collected within a research project ${ }^{6}$ realized at the Leibniz Institute for Regional Geography in Leipzig, Germany, in between August 2016 and May 2019. Ethnographic methods have been combined, in this project, with critical discourse analysis in order to investigate how the issue of 'migration' is negotiated in postmigrant urban societies in Germany's East and West. Participant observations, explorative walks, ethnographic conversations and interviews served as a means to explore this negotiation in everyday contexts, like youth clubs, neighbourhood centres and in public urban spaces. The fieldnotes I base my analysis on focus on the latter: They reflect the whole process of a political-artistic intervention carried out at Leipzig Main Station in November 2017. My ethnographic material, collected in between September and December 2017, covers six planning meetings, several visits and stays at the site before, during and after our intervention, the protest day itself and a follow-up meeting. The written protocols have been analysed inductively and deductively-against the backdrop of theoretical literature on contentious action, (abject) citizenship and space. I proceeded with a Grounded theory inspired coding technique (Corbin and Strauss 1990, Böhm 1994), beginning with a broad structuring of the material that included the selection of key passages in the text. As a second step, then, I used the tool of the "coding paradigm" (Corbin and Strauss 1990, p. 13) in order to analyse these key passages, always in dialogue with the entirety of the material, more closely. This helped me to identify key analytical categories around which I developed my argument: protest as disruptive (1), as affective (2) and fractured (3). I embed this analysis in a discursive context that I sketch very broadly in "Leipzig Main Station as a site of abjection" section. For the purpose of this contextual analysis, I combined a content analysis approach (Gheyle and Jacobs 2017) with a critical discourse analysis perspective (Fairclough 1995; Richardson 2007) that sensitized me particularly for the interplay between text, discursive practice and sociocultural processes (Fairclough 1995, p. 56). My aim, here is to outline Leipzig Main Station as a discursive arena where securitizing discourses, upgrading initiatives and the reproduction of ethnosexist discursive orders intertwine.

My personal role within the process was ambivalent: On the one hand, I acted as a researcher with the aim of producing critical knowledge on space-based, racializing politics that criminalize urban subjects and their strategies of counter-action.

\footnotetext{
${ }^{6}$ The research project "Locally Stranded, Globally Embedded? Dealing with Diversity on the Margins of the Postmigrant City" has been realized at the Leibniz Institute for Regional Geography, funded by the DFG (German Research foundation).
} 
On the other hand, I was "recruited" by a friend who equally addressed me due to my political connections with anti-racist struggle. During the fieldwork, I not only negotiated this biased role but, most centrally, my privileged position as a white woman with a stable income, social networks, without serious obstacles that might impede my envisioned personal trajectory at that time. So how was I entangled with the reproductions of power and difference within the group? The vignette presented above brings to the fore the most prominent lines and dynamics of differentiation related to my societal position: The police officer addresses me as a white woman, in a gesture of protection and complicity. The anticipated complicity grounds on whiteness, this "point from which the world unfolds" (Ahmed 2007, p. 154)—a line that separates our experiences and orientations in the group. Institutionalized racial boundaries, here, clash with my unstable position as a critical researcher and as an ally in anti-racist action. We could not be more divided than in this moment: Institutional power at white citizens' service on the one hand, coming towards black newcomers in the city as a threat, on the other. This violence lying within racial boundaries accompanied our project from the start. The situation in the vignette equally bears a gender-based invocation: Clearly, the policeman's protective gesture works on the grounds of a discourse that showcases female vulnerability in urban public spaces and restates male privilege. When, in the middle of our preparation period for the protest action, I suggested a bar in the city centre for a collective meeting, based on a quick google research, and the place turned out to be quite a fancy Irish pub, Walid looked at me, with a smirk: "You white Germans always choose these posh places". I was touched awkwardly by this comment, had I, without knowing this bar, "just" tried to find a place easy to reach for anybody. Walid, here, confronts me with my race- and class-related privilege. All of these discursive formations, in their complex and embodied intersections, materialized in another situation at the protest day itself, when, in the end, the protest turned into party. In my fieldnotes, I mark "unease/discomfort" as a feeling I started to have while becoming surrounded, in the dark, by male protesters drinking and dancing. Having started my paper with "post-Cologne" racial formations that produce abject bodies: This small word, "unease", places me in the centre of reproduction of postcolonial racial power that sorts bodies, affects, feelings and places. And lastly, of course, I enact power while sitting here, at home, on my chair, "researching about", writing and producing knowledge related to racialized subjectivities. In the concrete situation mentioned above, I tried to act against discomfort by addressing the people around me and engaging in conversations. Regarding my research, I adhere to Gillian Rose's acknowledgement of the "messiness" that prevails within methodological commitments to reflexivity related to my positionality and privilege (1997, p. 314/315). Recognizing that messiness means, for me, to think of my research practice and relations as performative acts "saturated with power, but also, paradoxically, with uncertainty" (ibid, p. 316/317). Hence, doing research not only remains messy, it is also irresolvably risky. I perceived this particular field research as a risk from the start. In the end, however, my wish to contribute to the counter-narration and re-performance of Leipzig Main Station as a site of knowledge, intimacy and connection won over my worries to reproduce exclusionary dynamics and erasures within the power landscapes I and the protesters find ourselves in. "Gulfs" emerged, but also 
"connections" (ibid, p. 317). Ultimately, I tried to turn moments of unease, irritation and tension into moments of learning, increased awareness and scientific, as well as political rigour. In sum, with this paper, I wish — on the one hand-to work productively on the grounds of the "messiness" (ibid, p. 314/315) we remain with, when reflecting our positionality and privilege in research processes. On the other hand, I want to interlink these reflections fruitfully with my overall aim to contribute to the construction of counter-narratives that unfold at this complex intersection of abjection, space and resistance.

\section{Abjection as a "theory of bordering"}

The theoretical concept of 'abjection' is ideally suited to unpack how spatial exclusion, movements of resistance and politics of difference intertwine. In this theoretical section, I will first give an overview over different conceptualizations of abjection and how I intend to make them fruitful for the analysis. Second, I will discuss the relationship between abjection and space and, third, briefly outline the related understanding of resistance.

\section{Abjection}

The concept was first introduced by Julia Kristeva who, in "The Powers of Horror: An Essay on Abjection" (1982) provides a near to lyrical account of abjection as an act of repulsion as well as of desire, one that simultaneously ejects and draws towards "embodied others" such as vomit, sex and death. Her psychoanalytical approach sounds abjection as a fundamental tension that lies within the subject. It is within this tension that Kristeva equally situates the potential of transgression: Transferred to the realms of the social, she sketches an ethics of encounter and dealing with this 'otherness' within, but also with the (national) 'stranger'. Here is where Imogen Tyler's conception of abjection, published in her book "Revolting Subjects: Social Abjection and Resistance in Neoliberal Britain" (2013) sets off: It grounds on Kristeva's original analysis but begins with a very fundamental critique of the latter. Firstly, she suggests that Kristeva's argument-especially when she uses her psychoanalytical theory of the abject to explain and even tackle xenophobia in Franceof being a-historical, ignoring the country's colonial past and ultimately fostering French nationalism (Tyler 2013, pp. 30-33). Secondly, Tyler argues, the concept's groundings in psychoanalysis reproduce Western/European universalism in being concerned with the "fear of and hatred for the foreigner" (ibid, p. 35) without taking into account the question of cultural and historical difference (cf. Spivak 1992). With her definition of abjection as a "neoliberal politics of disgust" through which "aversive emotions against minority subjects are instrumentalized as technologies for garnering public consent for the shift from protective liberal forms of welfare to disciplinary workfare regimes" (ibid, 26), Tyler aims at historicizing and politicizing the notion of abjection. It is turned into an analytical tool of social analysis. Judith Butlers account of abjection, written in "Bodies that matter" (1993), bridges the 
two conceptions: The author sounds the demarcation between and the interrelatedness of 'the abject' and 'the subject'. "The subject is constituted through the force of exclusion and abjection, one which produces a constitutive outside to the subject, an abjected outside, which is, after all, 'inside' the subject as its own founding repudiation" (Ibid, p. 3). The abject, Butler argues, designates "precisely those 'unlivable' and 'unthinkable' zones of social life" (ibid.) that function as a limit for the realm of the subject. A threat lies within this repudiation, Butler argues further-a disruptive potential that, ultimately, haunts the subject. In this paper, I use the concept of abjection in order to consider, on the one hand, how the interplay between state powers and subject formation unfolds along the (spatial) production of 'the abject' (Tyler 2013, p. 35; Butler 1993, p. 3). On the other hand, I will investigate how politics of abjection stimulate revolt and resistance (Tyler 2013, p. 5, Butler 1993, p. 3).

\section{Abjection and space}

Abjection is a profoundly spatial phenomenon. Likewise, spatial metaphors permeate its theorization, ranging from "abject zones" (ibid, p. 36), to an "abjected outside" (Butler 1993, p. 3) or "border spaces" (Tyler 2013, p. 36). The politics of emotion, abjection is based on, are said to be "spatializing" insofar as "the abjecting subject attempts to generate a space, a distinction, a border, between herself and the polluting object, thing or person" (ibid, p. 28). The notion of 'space', however, within the works cited, receives rather scant explicit and conceptual attention. In other analysis that uses the term (urban) spaces are more explicitly explored as the arenas where politics and practices of abjection unfold, generating individuals "considered worthless" (Sharkey and Shields 2008, p. 239) or "out-of-place" (ibid., p. 243, see also Isin and Rygiel 2007; England 2008; Özakin 2011)). "Abject space”, here, is conceptualized as a "point of convergence" (Sharkey and Shields 2008, p. 246), a "junctural site of contact" (ibid.) where the simplistic dichotomies of 'insider' and 'outsider', of 'centre' and 'margins' overlap (ibid, 242). Vighi et al. (2014) introduce the notion of "threshold" and advance an understanding of space as fractioned, overlapping and prone to transformation. Urban sites, from these perspectives, appear as contested arenas of struggle (Ehland and Fischer 2018, p. 9) where regulatory control and the exertion of (state) powers are countered by tactics of resistance, adaptation and solidary encounter.

\section{Abjection and resistance}

My understanding of resistance sets out from Tyler's definition of the "politics of the abject" as a "counter-spatial politics which attempts to reclaim the spaces and zones of abjection as radical sites of revolt and transformation" (Tyler 2013, p. 41/42). In order to defy against any 'romanticism' of critique, however, I draw on Butler's theory of performativity (Butler 1990) but also Paul Gilroy's notion of conviviality (2004): I think of resistance not as a deliberate act of contestation-in Butler's words, "condemned to the pathos of perpetual failure" (Butler 1993, p. 3) - but rather as a possibility of disruption and rearticulation. 'Abject bodies' who articulate 
their own "claim to autonomy and to life" (Butler 1993, p. 3) can interfere within the circular process of repetition and citation "by which discourse produces the effects that it names" (ibid., p. 2) and, potentially, emerge as bodies that matter. Convivial and solidary action, in this context, appear as a politics of difference that is inextricably intertwined with the racializing workings of European (post)colonial powers (Gilroy 2004).

\section{Empirical analysis}

In this empirical section, I will firstly map out Leipzig Main Station as a "site of abjection" which co-produces a normative urban subject, and, at the same time, as a "site of ambivalence" (Butler 1993, p. 125) which bears the potential of disruption. Secondly, then, I will investigate the Leipzig Main Station as a "border space" or "threshold zone" with a focus on the fractions and fragmentations that lie within abject space.

\section{Leipzig Main Station as a "site of abjection"}

The vignette which I have presented in the introductory section has made apparent that Leipzig Main Station is in the focus of local police forces. And indeed, this urban area is considered as 'pilot project' in Germany for dealing with the so-called "high crime areas"-initially through camera surveillance-since April 1996 (cf. Ullrich and Tullney 2012; Arzt and Ullrich 2004). Officially labelled as a "dangerous place", ${ }^{7}$ different structural measures are set up with the overall aim to increase "order, security, cleanliness" (Staeubert 2017): Classical music is played at the entrances in order to "improve the quality of stay" (Luc 2017) in and around the Station and the "local office for public order" (in German: Ordnungsamt ${ }^{8}$ ), since 2018, is upgraded and-in appearance-equated to a police authority. Lastly, plans are being made for privatizing the station's forecourt and thereby facilitate evictions: This transfer of competency from the local police authorities towards the German railway company will allow the application of much more restrictive measures through private security staff (Nagel 2018). This 'polic(sh)ing-mission', implemented in parallel to different urban development projects, ${ }^{9}$ is linked to a particular subject construction which, as we will see, combines notions of class, race and

\footnotetext{
7 This definition is "based on experiences" of police forces, as is said in the law text (Ullrich and Tullney 2012) and a concept of "crime prediction", in which the supposition of being confronted with "suspect people' suffices in order to implement repressive and controlling practices.

8 This office, in Germany and Austria, forms part of the administration of a city or a municipality and is responsible for public order and safety. Concerts, festivals and also demonstrations, for instance, have to be authorized by the „Ordnungsamt “.

9 The former luxury hotel "Astoria" is about to be restored in its former glory and in the in the previous "Crystal Palace" area-the biggest entertainment complex in the German Democratic Republic (GDR)a massive urban development project will be realized (175 apartments, 164 student rooms, 320 hotel rooms as also commercial spaces, Rometsch 2018).
} 
gender and leads us back to Butler and her conception of 'the abject'. For instance, homeless people who use the Station's forecourt for socializing, warming up and, of course, a source of income are driven out (Julke 2017; Nagel 2018). At the same time, the Station promotes itself as "Shopping Station" which hosts over a hundred shops, restaurants and snacks and is frequently used by partying crowds, at weekends, as a last opportunity to stock up on drinks. Abjection, here, targets sensory aspects of deviance like smells, appearance, noise and works along class differences.

A comparable "double" appellation, in which a 'desirable' citizen subject invokes, simultaneously, its 'discursive twin', the "cast out" abject, is reproduced along the category of 'race': Undocumented migrants appear, in the local discourse, as a further and central argument for increasing police presence and controlling/ repressive practices in and around the Main Station. Migration and criminality, within this argumentation, are discursively intertwined. The timespan between 2015 and 2016, in this regard, marks a significant rupture: Topic-oriented news reporting - as for example about drug-dealing — is growingly superseded by a rising number of articles which indicate ethnic references ${ }^{10}$ of suspects - via their nationality or descriptions indicating a "North African appearance" (luc 2018). "North Africans", or "North African criminal groups", very generally, are said to "dominate the drug-dealing-milieu" (Döring 2017; nöß, 2017; Kreuz 2018). The increase of problems around crime and violence — in numbers and shape-are explicitly associated with the "intensified stream of refugees" (Döring 2018b). References to "unusual" weapons used in violent confrontations like pales, billets and knives (Döring 2015), and the conflation of ethnicised criminality with the issue of sexuality, as through explicit references to "the assaults in Cologne" (Debksi 2016; Döring 2018a), conjure the image of the 'demonic other' (Mecheril and do Mar Castro Varela 2016). 'The abject', here, within repetitive loops, is reproduced as a 'male, undocumented immigrant of colour implied in murky affairs' - a construction which co-produces the white urban middle-class consumer subject-regular income, stable living conditions, no migration background. An increasing interest in Leipzig Main Station as the city's 'business card' which represents its urban development and attractiveness promotes the construction of 'desired customers' like business commuters, tourists and shoppers.

Here is where the protest action introduced in the beginning of my article intervenes. It aims precisely at irritating the discursive configuration sketched above in positioning abject beings as active citizens who decide upon their lives and articulate their stories in public. Staying with Butler, I will sound, in the following, the disruptive potential or in her words "critical resource" (Butler 1993, p. 3) that lies within their performance. Does it represent one of these "occasional spaces in which those annihilating norms, those killing ideals of gender and race, are mimed,

\footnotetext{
10 In March 2017, the German Press Council modifies its directive in regard to the coverage of criminal offences: While, before, journalists were advised only to refer to affiliations of suspects to religious, ethnic or other minorities "if a justifiable factual concern existed" (Presserat 2017), since the happenings in Cologne, the formula of "public interest" is introduced into the directive, which marks a backsliding from the principle of non-mention.
} 
reworked, resignified" (Butler 1993, p. 125)? Butler asks three leading questions: "How does the unspeakable population speak and makes its claims? What kind of disruption is this within the field of power? And how can such populations lay claim to what they require?" (Butler 2015) Answers to these questions can only be fragmentary. Furthermore, there is reason for doubt whether this protest can unfold a truly subversive potential (Butler 1993, p. 121 ff.). The protesters' administrative situation remains untouched, even more so, taking part in this activity puts the protesters, who find themselves under a constant threat of eviction and expulsion, severely at risk. However, I identified three articulations which bear, in my eyes, "disruptive" potential insofar, as they, at least momentarily, disturbed the visual, affective and bodily regimes that, here, constitute 'abject space', its atmosphere of restlessness, distress and also violence.

Voice, especially when performed with a particular affective intensity, as for instance anger, marked an interruption insofar as people who had not embodied any visible political presence in Leipzig, in Eastern Germany so far, stepped on stage, spoke out, sang or performed rap music. Mattering, or rather the process of emerging-as-subjects (that matter), here, arises from a space of ambivalence oscillating between political legibility ('voice') and illegibility ('noise') (see Rancière 1999). Walid's theatre performance, as a matter of fact, did not represent a pleasing cosmopolitan plead, but most of all an embodiment of the pain, anxiety and distress which the European external border exerts on bodies and subjectivities detained outside Europe. When his voice shrilled over the square, one friend of mine asked: "Why does he shout so angrily?" His performance was indeed disturbing. The bodily proclamation of anger and grief disrupted the boundaries of 'abject space' and reversed the "politics of disgust" (Tyler 2013) he and others feel subject to. A comparable political vigour unfolded from the practice of dancing, especially when it reached out - momentarily - into the pedestrian area which was, at this time of the day, marked by purposeful, swift walking. When Draven, Grace, Fabrice and others paused their flyer-dispatching activity and started to dance, as later did some of the people regularly hang out at this place, I felt that this was disruptive: their movements were not shy or cautious, but quite expressive, space-taking, and a bit ironic. This unusual picture provoked irritated looks: People who are generally associated to murky affairs and suspicious lingering performed hilarious dance moves. Their movements, in this context, represented "a kind of corporeal micro-politics" (McCormack 2008, p. 1826) that subverted the ostensible regularity and linearity an urban-middle-class-after-work scenario. A similar unsettling potential emanated from the moment when protest transmuted, at the end of our action, to party: The stage had been opened, rap music was improvised, conviviality and solidarity were conjured-or rather: "brotherhood"—as the crowd was nearly exclusively composed of men. "We are here from Cameroun, from Yaoundé, from Tunesia, from Eritrea, from Germany and together we..." (Fieldnotes, 21.11.2017). People were cheering. What was enacted here is the ideal of 'conviviality' as it has been theorized, prominently, by Paul Gilroy (2004): The 'becoming-insignificant' of (ethnic) difference, in this context, is precisely not about cherishing commonalities across racial boundaries - a majoritarian, liberal phantasy that is rooted in 'whiteness' and rather oblivious of Europe's colonial past. The protesters' fraternal gestures rather reflect a 
shared consciousness of the workings of European racism that produces difference (via concepts like 'minority', 'culture' and '(ethnic) identity'). They mark a (deconstructive) desire and drive to 'step out of' and go beyond these demarcating logics understood as remnants of the European colonial project. Put shortly: One finds oneself in an 'unruly' connection critical of the latter. Accordingly, Walid announced "a German song to finish"- “Casablanca, Casablanca", an ironic song about marijuana with relation to North Africa, a hymn to the dealer playboy in his kingdom of trash. The crowd went crazy and sang along. For a moment, this place-their place-turned into a place of joy.

To sum up: Message and voice were only one register via which non-European subjects, throughout the protest, claimed political citizenship. It were particularly the affective, embodied articulations like dance, singing and joint cheering-articulations which exceeded the classical realms of political (legible) speech-that disrupted the spatial confines of consumption and control that, in this context, produce 'abject space'. In the next paragraph, I will provide a more nuanced analysis of the latter in focussing on the fractions and fragmentations that living-in-abjection entails.

\section{Abjection-as-resistance: sounding and negotiating the "threshold zone"}

The notion of "threshold zone" (Vighi et al. 2014), where "in" and "out" are blurred, here, serves as a framing. It proves helpful in order to grasp the ambivalent social configuration produced by the discursive formation sketched above: While the spatial and social arrangements I encountered throughout my temporal visits and stays were, on the one hand, characterized by fragility and frailty, I just as clearly experienced this urban setting as an area of expertise, knowledge and intimacy. Especially the park area located alongside the pedestrian zone, which interlinks the Main Station with the City Centre, revealed as a site marked by a variety of practices ensuring survival and mutual care - the trade of information, jobs, goods, intimacy-but equally exposing struggle and violence, mainly with regard to sparse income opportunities. What might appear as an isolated "space of exclusion" at first sight, reveals, at closer look, as a site which has been creatively appropriated by 'abject subjects' who act as 'locals' here, who command a certain residency, or mastering, and who, depending upon the situation, radiate comfort and ease, boredom or despair. "We are all friends here", one young man tells me at the day of our protest action. While this euphoric acclamation might not hold true for everyone and every situation, the micro-politics of familiarity and support which have evolved here defy the violence enacted against a community of urban dwellers which is placed outside any legal migration framework but in the heart of national discourse advancing anti-immigration claims. This urban area has been appropriated through social practices of solidarity, the circulation of knowledge and intimacy. It represents, indeed, a "threshold zone" where regulation and control also incite tactical movements of evasion and recapturing - where "people made abject" also take place. 
These (ambiguous) possibilities of "taking place", however, depend on the particular, subjective experiences of being made abject— the status held, the social position ascribed to. This is why I ask, in the first place: Who can protest-and how? Which spatial arrangements does it require-for whom-in order to step out—be seen — and raise his/her voice-be heard? 'Abject space', when becoming a ground for protest, bears 'internal zonings'. As the following extract of my fieldnotes, which forms part of the material presented in the introduction, illustrates, these subdivisions become traceable along the qualities of light and dark:

"We stroll from left to right, across the pedestrian zone, in between two parks, and ponder upon a suitable place for the performance: On the right, it is too bright-Walid imagines a dark walkway in the park, so that his shadow performance can really stand out. Later I understand that he also intends to include those who occupy the benches in daytime and at night and struggle for the sparse opportunities to make a living through drug trade" (Fieldnotes, 6.11.2017).

In the end, we agreed on a site situated in between the floodlit pedestrian passage which interlinks the Main Station with the City Centre, and the small park, lying in dim light, comprising also dark zones covered by trees and bushes. In his works on illumination and darkness, cultural geographer Tim Edensor examines the interplay of light and power/authority. He explores darkness, in contrast, in its potential to allow alternative and resistant articulations to emerge: "particular practices, cultural values and conceptions circulate around gloom" (Edensor 2015, p. 559). Throughout our protest, these "zonings" tied to "luminosity and murkiness" (ibid.) proved essential in order to allow diverse subjectivities to take part within the activity: While Fabrice, Draven and Grace, who form part of the Cameroonian refugee community in Leipzig, spread out across the pedestrian space in order to dispatch flyers and interact with passers-by, the young men of mostly North African background, who are tied more closely to this urban area and take part in our activity only at this particular day, remained in the shady areas and only occasionally entered the floodlit area. Placing our tent in the threshold proved crucial: It allowed the ones, who felt safe and protected, to step out and on stage, to embrace visibility and engage in dialogues, while safety and seclusion was provided for those who were forced to constantly play "hide and seek" with the police. Our collective appropriation of 'abject space', in this regard, followed the shifting geographies of light and dark, coining and constantly reshuffling comfort zones and spaces of intrusion. Momentarily, these boundaries and fractions were overcome: I could observe a constant movement in between lit and dark zones-some participants approached the "centre", without however embracing the "spotlight", while others hid behind the protective panels of our tent but used to microphone to raise their voice. What Walid, at first, regretted as a "mistake" - the pavilion being closed towards the pedestrian area-turned into an asset. In sum, paying attention to lighting conditions uncovers the internal "zonings" of abject space-how subjects-made-abject in different ways move across and take up space, affirming and momentarily overcoming the boundaries set by the matrix of power yarned around the Main Station. 
Murkiness, here, unfolds its empowering, enabling, inclusive qualities, while floodlit spaces of control—as demonstrated above—are disrupted by "inappropriate" conduct, as for instance dance.

After having investigated spatial and atmospheric conditions of abjection-asresistance, I will, in the next sub-section, turn to the discursive layering and fracturing of abject space: Who is made abject and how? What about the differences, intersections and negotiations within abjection? Abject space, as I will argue, is not only a "junctural site of contact" (Sharkey and Shields 2008, 246) with regard to regulation and control on the one hand and tactical resistance and the enactment of abject citizenship on the other. What also converges here, are differing discursive interpellations which "make" the abject and create, hence, fractions and tensions within the process of resistance. The following extract of my fieldnotes mirrors an interruption in our planning procedure and how a process of re-negotiation-regarding our aims and target group — set off when one part of the group felt silenced, or rather: bypassed:

We are discussing the text on the flyer. "Is that okay with you?" Walid asks. Draven, then, criticizes the focus on North Africa: ,If we shall mobilize people for next Monday, and tell them, 'there will be a rally' and 'it's about NorthAfrica' and not West-Africa, Subsaharian Africa etc. ...' He shows with a gesture: 'Our people', in the centre for refugee accommodation, would feel hosed. Criminalization is a problem for the whole of Africa-the border is the problem, a problem of papers. This does not only concern North-Africa.' Fabrice adds then: 'Perhaps at the Main Station, there are many North Africans but people from other African countries are pushed into other criminal niches. The problem is a general one." Walid looks tense and defends his draft. Awkward silence. Grace, then, adds that "all is about to coming from the particular to the general". In her view, the problem is racist stereotypes against Africans in Germany. It is the first time that Draven, Grace and Fabrice actively participate in the discussion. I can feel that this is somehow a "concerted action"”.

Helga Leitner et al.'s space-based approach to contentious politics (Leitner et al. 2008) proves helpful in order to dissect "the differences within all collective action" (ibid., 157). What the conflict sketched above illustrates, are the various discursive modes along which different subjects are being made abject. While Grace, Draven and Fabrice, first of all, negotiate a position of non-citizenship and political invisibility, Walid-representing the political situation of North Africans in Germany-formulates his protest from a position of legal exclusion and discursive (hyper)visibility. His intention is to articulate a performative response to Post- "Cologne"-national discourses on North African migrants, embedded in a critique of the European border regime and leftist claims. The intervention of Draven, Grace and Fabrice aims at re-orienting the protest from the particularity of racializing discourses that (in) visibilize migrants in Germany towards the shared experience of being hardly considered within the German asylum regime. In sum, these negotiations demonstrate in what way 'abject space' constitutes a site where variegated forms of privilege and discrimination are negotiated. Beyond that, however, they make apparent how these fractions affect solidary action: It seems as if Fabrice, Draven and Grace, within the 
moment described above, resist against being mere "accessories" of the project—if they risk their status in participating at a rally in a highly policed area as the Hauptbahnhof, then, for giving voice to their situation, for being heard with their stories in public. This situation demonstrates how the cohesion in our group is, for a moment, undermined by our differences in status, citizenship and privilege/power- "alliance politics" reveal as highly fragile. The fractures 'abject space' bears bring to the fore the multiple, overlapping subjectivities and strategies which intersect here, as well as the various realities forged by different "abject zones" in the city-refugee accommodations, street corners, parks. As a ground for protest, this "meeting place", or "overlap space" (cf. Sharkey and Shields 2008, p. 246) can turn into a space of tension which requires constant negotiation and adjustment.

\section{Concluding remarks}

The aim of this paper was to make the theoretical notion of 'abjection' fruitful for the analysis of a local protest intervention that reclaimed a highly policed urban space in the city of Leipzig. Butler's theorization of 'the abject' helped me to shed light on the formative power of spatial exclusion: Discursive orders that reproduce non-European urban dwellers in irregular living conditions as a threat for the urban integrity symbolically construct Leipzig Main Station as a 'white' space which embraces the middle-class consumer subject. Butler's reflection on the (im)possibilities of subversion served as a tool for sounding the disruptive potential of protestthe confined means of 'abject beings' to enlarge regimes of political legitimacy and legibility and emerge as subjects that matter. Voice, dance and celebration, in my analysis, were identified as articulations that bear the potential to shake up the bounded spaces reserved to who counts as "legitimate" subject.

Theoretical accounts in which 'abjection' is conceived as a "threshold zone" or "overlap space", then, allowed me to focus on 'abject space' as a space of negotiation and contradiction. Abjection, here, appears as a nuanced, variegated regime of exclusion that constantly reshuffles the spatial boundaries of 'inside' and 'outside'. I could trace these processes of negotiation while paying attention, firstly, to the conditions of light and dark within protest: Some protesters felt empowered to enter one of the most floodlighted of all urban areas, the Station's forecourt, while others, due to their status and social position ascribed to, relied on spheres of darkness and shade in order to voice their concerns. Secondly, I examined an internal conflict that arose between participants of the intervention with regard to the representation of their particular concerns in the protest, formulated onto the ground of their particular discursive position in Germany. I could demonstrate that different ways of being made abject_as "migrants" or "illegal migrants" or "North Africans" or "male migrants"-matter for how critique is enacted and require negotiation and adjustment within the conception and execution of protest.

I will close my article with a last reflection on (the limits of) subversion already discernible in Butler's reflection: Which effects can a temporary protest as it has been enacted can unfold in the long run? In the last paragraph of the introduction to Revolting Subjects, Imogen Tyler states that “...it is often not events of protest, 
or resistance themselves, many of which barely register within the public domain or are quickly forgotten or suppressed, but rather the storying of revolts-and the forms of aesthetics this affects-which matters most" (Tyler 2013, p. 12/13). In this light, one could say that the protest action performed at Leipzig Main Station in November 2017 has barely had transformative impact: It was by no means comparable to the diverse manifestations of voice and claim that Nyer, for instance, sketches in his well-known article "No one is illegal between city and nation" (2008)—rallies, marches, hunger strikes and occupations, mediated through images and other forms of representations across the globe. However, I argue, it provoked change in at least two regards. Firstly, it induced the formation of new geographies of presence and visibility: 'Stepping out' of the invisible zones of 'abject space' into the representative arenas of the urban centre, adopting the subjectivity of a protester, forming a crowd, or "just having fun"-under the protection of "legal" protest—all of these manifestations contribute to the reformulation and reinterpretation of (self-) understandings with regard to the states of exclusion and marginality. Even more importantly, however, they constitute an entering the city anew-the city as a political space.

These findings gain in importance when being discussed in the light of the particularities of Eastern German urban societies of migration, hinted at in footnote 4: The city of Leipzig is exemplary for an urban context in which migration-related diversity only gradually gains in visibility and presence. While the self-image and historically embedded narrative of a "cosmopolitan city" is reiterated like a mantra within processes of upscaling and competitive urbanism, the diversification of formal and informal urban infrastructures, respective of the re-fabrication of the urban everyday by translocally positioned subjects, remains in its early stages (Wiest and Kirndörfer 2019). Critical visibilities and intimacies of young people of colour in a mundane and yet representative urban area like the Hauptbahnhof produce productive ruptures within both discursive strands: Firstly, with the one that reproduces Leipzig as a "cosmopolitan" city constructed as beyond the need of critically negotiating issues of race and diversity within its institutional and everyday life spaces. Secondly, with the national discourse that constructs the German East as "lagging behind" in matters of migration and diversity and of being more "prone" to rightwing activism and extremism than the West (Hörschelmann 1997; Pates 2013; Matthäus and Kubiak 2016 and forthcoming, Foroutan and Hensel 2020). Through intimate and critical connections, citizens made abject weave themselves into the urban fabric. People of colours' invisibility in the urban landscape is scrutinized, while at the same time, the city of Leipzig is turned into a site of migrant activism.

Secondly, beyond these rather manifest and 'tangible' effects of our protest, I would like to highlight the "[s]eemingly minor and mundane things" that-according to William Walters (2008, p. 191)—equally form "a kind of politics" (ibid., 193). Walters adopts and slightly twists the "acts of citizenship"-perspective introduced by Isin and Nielsen (2008) in stating that political action is not restricted to formations of "See/hear us, recognize us, respect us, empower us!" (Ibid., 194) The metaphor of the "threshold zone" which I have fertilized in the course of this paper, indeed, hints at the diverse "minor ways" in which differently positioned subjects move across, exceed and challenge or remain within spatial confines and subjective 
boundaries. My aim was to emphasize the articulate and inarticulate, the affective, imaginary and ambiguous expressions of being/becoming political and on the fractures and tensions within 'abject space'. While I might run the risk of-in Tyler's words- "fetishizing 'the event' by inflating the meaning and potential of protests as moments of political hope for the future" (Tyler 2013, p. 12), I want to end on an optimistic note: Resistant movements against intensifying modes of abjection, however "minor" they might be, forge new political spaces, new imaginaries and have the power to perform what Walters calls a "space of possibility which at any given moment surrounds our political identities" (Walters 2008, p. 204).

Funding Open Access funding enabled and organized by Projekt DEAL.

Open Access This article is licensed under a Creative Commons Attribution 4.0 International License, which permits use, sharing, adaptation, distribution and reproduction in any medium or format, as long as you give appropriate credit to the original author(s) and the source, provide a link to the Creative Commons licence, and indicate if changes were made. The images or other third party material in this article are included in the article's Creative Commons licence, unless indicated otherwise in a credit line to the material. If material is not included in the article's Creative Commons licence and your intended use is not permitted by statutory regulation or exceeds the permitted use, you will need to obtain permission directly from the copyright holder. To view a copy of this licence, visit http://creativecommons.org/licen ses/by/4.0/.

\section{References}

Ahmed, S. 2006. Queer phenomenology: Orientations, objects, others. Durham: Duke University Press. Ahmed, S. 2007. A phenomenology of whiteness. Feminist Theory 8 (2): 149-168.

Arendt, F., H.-B. Brosius, and P. Hauck. 2017. Die Auswirkung des Schlüsselereignisses "Silvesternacht in Köln” auf die Kriminalitätsberichterstattung. Publizistik 62: 135-152.

Arzt, M., P. Ullrich. 2004. City monitoring. Jungle world, 32/04. http://jungle-world.com/artikel/2004/32/ 13405.html. Accessed 5 Oct 2012.

Boehm, A. 1994. Grounded theory-wie aus Texten Modelle und Theorien gemacht werden. In Texte verstehen: Konzepte, Methoden, Werkzeuge, ed. A. Boehm, A. Mengel, and T. Muhr, 121-140. Konstanz: UKV Univ-Verlag.

Butler, J. 1990. Gender trouble: Feminism and the subversion of identity. New York: Routledge.

Butler, J. 1993. Bodies that matter. New York: Routledge.

Butler, J. 2015. Notes toward a performative theory of assembly. Cambridge: Harvard University Press.

Castro Varela, M., and P. Mecheril. 2016. Die Dämonisierung der Anderen. Rassismuskritik der Gegenwart. Bielefeld: transcript.

Corbin, J. M., and A. Strauss. 1990. Grounded theory research: Procedures, canons, and evaluative criteria. Qualitative Sociology 13: 3-21.

Debksi, A. 2016. Schon 295 „Antänzer“ in Datei der Leipziger Polizei erfasst“, Leipziger Volkszeitung, 29.10 .

Deutscher Presserat. 2017. Neue Richtlinien 12.1.—Berichterstattung über Straftaten. https://www.press erat.de/fileadmin/user_upload/Aktuelles/UEbersicht_bisherige_Richtlinie_neue_Richtlinie12.1.pdf. Accessed 19 Feb 2019.

Dietze, G. 2016a. Das 'Ereignis Köln.' Femina Politica 1 (2016): 93-102.

Dietze, G. 2016b. Ethnosexismus. Sex-Mob-Narrative um die Kölner Silvesternacht. In: Rassismus in der postmigrantischen Gesellschaft eds. Espahangizi, K., Hess, S., Karakayali, J., Kasparek, B., Pagano, S., Rodatz, M., Tsianos, V. movements 2(1), pp. 177-185 
Döring, F. 2015. Marrokkaner nach Messerstichen in Lebensgefahr, Leipziger Volkszeitung. http://www. lvz.de/Leipzig/Polizeiticker/Polizeiticker-Leipzig/Marokkaner-nach-Messerstichen-in-Lebensgefa hr. Accessed 22 Feb 2019.

Döring, F. 2017. Razzia gegen Drogenszene rund um den Leipziger Hauptbahnhof, Leipziger Volkszeitung, 13.6. http://www.lvz.de/Leipzig/Polizeiticker/Polizeiticker-Leipzig/Razzia-gegen-Droge nszene-rund-um-Leipziger-Hauptbahnhof. Accessed 22 Feb 2019.

Döring, F. 2018a. Vorlage im Stadtrat. Angst vor Dealern: Leipziger Opernmitarbeiter fürchten Übergriffe, Leipziger Volkszeitung, 24.1. http://www.lvz.de/Leipzig/Polizeiticker/Polizeiticker-Leipzig/ Angst-vor-Dealern-Leipziger-Opernmitarbeiter-fuerchten-Uebergriffe. Accessed 22 Feb 2019.

Döring, F. 2018b. Brennpunkt Drogenhandel: Razzien schrecken kaum ab, Leipziger Volkszeitung, 24.03. https://www.pressreader.com/germany/leipziger-volkszeitung/20180324/282321090548357. Accessed 22 Feb 2019.

Edensor, T. 2015. Introduction to geographies of darkness. Cultural Geographies 22 (4): 559-565.

Ehland, C., and P. Fischer, eds. 2018. Resistance and the city: Negotiating urban identities: Race, class and gender. Amsterdam: BRILL/RODOPI.

England, M. 2008. Stay out of drug areas: Drugs, othering and regulation of public space in Seattle, Washington. Space and Polity 12 (02): 197-213.

Espahangizi, et al. 2016. Rassismus in der postmigrantischen Gesellschaft. Movements. Journal für Critical Migration and Border Regime Studies 2(1). http://movements-journal.org/issues/03.rassismus/01.espah angizi,hess,karakayali,kasparek,pagano,rodatz,tsianos--rassismus-in-der-postmigrantischen-gesellscha ft.html.

Fairclough, N. 1995. Media discourse. London: Arnold.

Farris, S. 2016. Die politische Ökonomie des Femonationalismus. Feministische Studien 29 (2): 321-334.

Fieldnotes, 2.11.2017: First meeting with Walid.

Fieldnotes, 6.22.2017: Inspection of the site.

Fieldnotes, 9.11.2017: First preparation meeting.

Fieldnotes, 13.11.2017: Second preparation meeting.

Fieldnotes, 21.11.2017: The day of the protest action.

Fieldnotes, 4.12.2017: Follow-up meeting.

Foroutan, N., and J. Hensel. 2020. Die Gesellschaft der Anderen. Berlin: Aufbau-Verlag.

Gilroy, P. 2004. After empire: Melancholia or convivial culture? London: Routledge.

Gheyle, N., and T. Jacobs. 2017. Content analysis: A short overview. Internal research note.

Großmann, K., A. Haase, K. Kullmann, and C. Hedtke. 2014. Assessment of urban policies in Leipzig, Germany. Department of Urban and Environmental Sociology. Helmholtz Centre for Environmental Research-UFZ.

Hark, S., and P.-I. Villa. 2017. Unterscheiden und Herrschen. Ein Essay zu den ambivalenten Verflechtungen von Rassismus, Sexismus und Feminismus in der Gegenwart. Bielefeld: transcript.

Hörschelmann, K. 1997. Watching the East: constructions of 'otherness' in TV representations of East Germany. Applied Geography 17 (4): 385-396.

Isin, E.F., and G.M. Nielsen, eds. 2008. Acts of citizenship. New York: Zed Books.

Isin, E.F., and K. Rygiel. 2007. Abject spaces: frontiers, zones, camps. In The Logics Of Biopower And The War On Terror, ed. E. Dauphinee and C. Masters, 181-203. New York: Palgrave Macmillan.

Julke, R. 2017. Musikbeschallung am Leipzig Hauptbahnhof. Ist Beethoven tatsächlich das letzte Mittel gegen Trinker, Junkies und Obdachlose?, Leipziger Internetzeitung, 10, July. https://www.l-iz.de/polit $\mathrm{ik} /$ brennpunkt/2017/07/Ist-Beethoven-tatsaechlich-das-letzte-Mittel-gegen-Trinker-Junkies-und-Obdac hlose-185023. Accessed 17 Feb 2019.

Kreuz, S. 2018. Tatort Leipziger Hauptbahnhof: Diebstähle und Gewaltdelikte nehmen zu, Leipziger Volkszeitung, 18, July. http://www.lvz.de/Leipzig/Polizeiticker/Polizeiticker-Leipzig/Tatort-Leipziger-Haupt bahnhof-Diebstaehle-und-Gewaltdelikte-nehmen-zu. Accessed 07 Dec 2018.

Kristeva, J. 1982. Powers of horror. An essay on abjection. New York: Columbia University Press.

Leitner, H., E. Sheppard, and K.M. Sziarto. 2008. The spatialities of contentious politics. Transactions of the Institute for British Geographers New Series 33 (2): 157-172.

Luc. 2017. Klassische Musik löst Probleme am Hauptbahnhof nicht', Leipziger Volkszeitung, 28, August. http://www.lvz.de/Leipzig/Lokales/Nagel-Klassische-Musik-loest-Probleme-am-Leipziger-Hauptbahnh of-nichtMecheril. do Mar Castro-Varela, M. (eds.) 2016. Die Dämonisierung der Anderen. Bielefeld: transcript Verlag. 
Luc. 2018. Messerangriffe und Körperverletzungen am Leipziger Hauptbahnhof, Leipziger Volkszeitung, 23, July. http://www.lvz.de/Leipzig/Polizeiticker/Polizeiticker-Leipzig/Mehrere-Gewalttaten-am-Woche nende-am-Leipziger-Hauptbahnhof. Accessed 22 Nov 2018.

Matthäus, S. (ed.) forthcoming. Der andere Blick auf »den Osten«. Zum Paradigmenwechsel in der Ostdeutschlandforschung. Bielefeld: transcript.

Matthäus, S., and D. Kubiak (eds.). 2016 (Hrsg.). 'Der Osten'-Neue sozialwissenschaftliche Perspektiven auf einen komplexen Gegenstand jenseits von Verurteilung und Verklärung. Wiesbaden: Springer.

McCormack, D. 2008. Geographies for moving bodies. Geography. Compass 2 (6): 1822-1836.

Münch, S. 2013. Rahmenbedingungen von Zuwanderung und interkulturellem Zusammenleben in den ostdeutschen Bundesländern - eine Bestandsaufnahme. Raumforschung Und Raumordnung 71 (3): 261-271.

Nagel, J. 2018. Der öffentliche Raum gehört allen: Probleme am Hauptbahnhof kommunikativ \& sozial lösen, jule.linxxnet.de, 19, April. https://jule.linxxnet.de/index.php/2018/04/der-oeffentliche-raumgehoert-allen-probleme-am-hauptbahnhof-kommunikativ-sozial-loesen/ Accessed 8 Jan 2019.

nöß. 2017. Vier Festnahmen nach Drogen-Razzien um Leipziger Hauptbahnhof, Leipziger Volkszeitung, 14, June. http://www.lvz.de/Leipzig/Polizeiticker/Polizeiticker-Leipzig/Vier-Festnahmen-bei-Polizei-Razzia-am-Leipziger-Hauptbahnhof. Accessed 16 Feb 2019.

Nyer, P. 2008. No one is illegal between city and nation. In Acts of citizenship, ed. E.F. Isin and G.M. Nielsen, 160-181. New York: Zed Books.

Office for Statistics and Elections. 2018. Migrants in Leipzig 2018. https://www.leipzig.de/fileadmin/medie ndatenbank/leipzig-de/Stadt/02.1_Dez1_Allgemeine_Verwaltung/12_Statistik_und_Wahlen/Statistik/ Leipzig_fb_Migranten.pdf. Accessed 26 Feb 2019.

Özakin, Ö. 2011. Space, identity, and abjection: Purification of Beyoglu. Dissertation submitted to the Department of Interior Architecture and Environmental Design and the Institut Oeconmics and Social Sciences of Bilkent University. http://www.thesis.bilkent.edu.tr/0006322.pdf. Accessed 22 Feb 2019.

Pates, R. 2013. Der "Ossi". Mikropolitische Studien über einen symbolischen Ausländer. Wiesbaden: Springer.

Philipps, A., and D. Rink. 2009. Zuwanderung und Integrationspolitik in einer schrumpfenden Stadt. Das Beispiel Leipzig. In: Lokale Integrationspolitik in der Einwanderungsgesellschaft - Migration und Integration als Herausforderungen von Kommunen eds by Gesemann, F. \& Roth, R., VS Verlag für Sozialwissenschaften: Wiesbaden, pp. 399-414.

Rancière, J. 1999. Disagreement: Politics and philosophy. Minneapolis: University of Minnesota Press.

Richardson, J. 2007. Analysing newspapers: An approach from critical discourse analysis. London: Palgrave.

Rometsch, J. 2018. Leipziger Krystallpalast-Areal: Baustart erst 2019, Leipziger Volkszeitung, 11, March. http://www.lvz.de/Leipzig/Lokales/Leipziger-Krystallpalast-Areal-Baustart-erst-2019. Accessed 16 Feb 2019.

Rose, G. 1997. Situating knowledges: positionality, reflexivities and other tactics. In: Progress in Human Geography 21 (3): 305-320.

Sharkey, A., and R. Shields. 2008. Abject citizenship-Rethinking exclusion and inclusion: Participation, criminality and community at a small town youth centre. Children's Geographies 6 (3): 239-256.

Staeubert, K. 2017. Polizeibehörde kommt Ende März, Leipziger Volkszeitung, 14, December. https://www. pressreader.com/germany/leipziger-volkszeitung/20171214/282252370876591. Accessed: 16 Feb 2019.

Spivak, G. 1992. Extreme Eurocentrism. Lusitania 1 (4): 55-60.

Tyler, I. 2013. Revolting subjects. Social abjection and resistance in Neoliberal Britain. London: Zed Books.

Ullrich, P., and M. Tullney. 2012. Die Konstruktion ,gefährlicher Orte‘. Sozialraum.de: https://www.sozia lraum.de/die-konstruktion-gefaehrlicher-orte.php. Accessed 22 Feb 2019.

Vighi, F., A. Nuselovici, and M. Ponzi, eds. 2014. Between urban topographies and political spaces. Threshold experiences. Lanham: Lexington Books.

Vollmer, B., and S. Karakayali. 2017. The volatility of the discourse on refugees in Germany. Journal of Immigrant \& Refugee Studies. 16 (1-2): 118-139.

Walters, W. 2008. Acts of demonstration: Mapping the territory of (non-)citizenship. In Acts of citizenship, ed. E.F. Isin and G.M. Nielsen, 182-206. New York: Zed Books.

Wiest, K., and E. Kirndörfer. 2019. Paradoxe Aushandlungen von Migration im Diskurs um die Leipziger Eisenbahnstraße. Raumforschung Und Raumordnung. 77 (6): 583-600. 
Publisher's Note Springer Nature remains neutral with regard to jurisdictional claims in published maps and institutional affiliations.

Elisabeth Kirndörfer holds a PhD in Social and Cultural Anthropology and an MA in Sociocultural Studies from the European University Viadrina, Germany. Her main research interests focus on critical migration theory, translocal biographies and (post)migration phenomena. As a postdoctoral researcher, she has been working until May 2019 in a research project on "The postmigrant city" at the Leibniz Institute for Regional Geography in Leipzig (Germany). Currently, she is in the course of completing her engagement in a HERA-funded European joint research on "The everyday experiences of young refugees and asylum seekers in public space". 